ANNALES

UNIVERSITATIS MARIAE CURIE-SKŁODOWSKA

LUBLIN - POLONIA

VOL. LXXII, 1

SECTIO AA

2017

\title{
The sorption capability of halloysite
}

\author{
Małgorzata Skibińska \\ Faculty of Chemistry, Department of Crystallography, \\ Maria Curie-Sklodowska University \\ Pl. M. Curie-Sktodowskiej 3, 20-031 Lublin, Poland \\ e-mail: malgorzata_skibinska90@wp.pl
}

Halloysite is commonly occuring in Poland a natural mineral which, due to its structure is very popular among researchers. First of all, the large number of sorption areas and their various selectivity makes the material capable of adsorbing the compounds of different nature at the same time. As a result, there is a lot of possible applications. In addition, ease of functionalization of the surface of the material increases its sorption capacity and makes its more attractive.

\section{INTRODUCTION}

Natural minerals, due to their structure, are used in many industries, environmental protection, but particularly important is their application in sorption processes. Adsorption is one of the highly effective and relatively inexpensive techniques used in water treatment.

Good adsorbent should be characterized by high adsorption capacity due to high specific surface and pore size, high selectivity, good mechanical properties, stability and strength and low production costs. The most famous adsor-bents

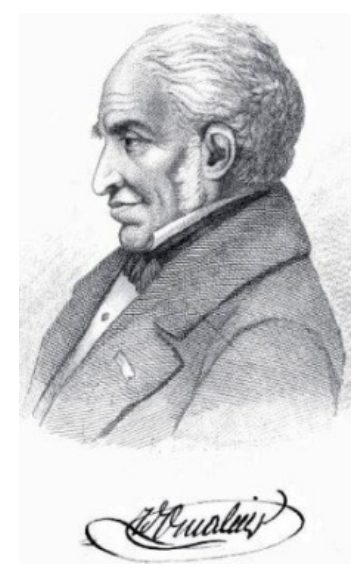


include activated carbon, silica, however, there are still ongoing studies on the possibility of receiving new, cheaper materials with high sorption capacity $[1,2]$. Natural minerals are more attractive here because of their prevalence and low costs.

One of the representatives of this group of minerals is halloysite. It belongs to the aluminosilicate group, where the $\mathrm{Al}: \mathrm{Si}$ ratio is 1:1. Halloysite was first described by Berthier in 1826 [3]. It is chemically similar to kaolinite, there is an empty structure in it. It can be in the form of long tubes, which, in terms of morphology, remind carbon nanotubes. The name of the mineral comes from its discoverer O. d'Halloy, who in the eighteenth century was the first who analized the structure of this mineral. It is extracted in China, France, Belgium, New Zealand.

However, its largest deposits are located in Poland. Extraction at the Dunino mine, located near Legnica, equals 12 million tons per year. Halloysite belongs to the group of double layer minerals [4]. Due to its properties and structure, it is easy to modify and enhance potential applications. High porosity, surface area and ion exchange make it highly popular among researchers $[5,6,7]$. In particular, it is widely used in the sorption process of dyes, biologically active substances $[8,9,10,11]$.

\section{CHARACTERIZATION OF MINERAL}

Halloysite is formed from kaolinite as a result of hydrothermal and geological processes. It often occurs in soils of volcanic areas [12]. It has a white color. However, sometimes $\mathrm{Al}$ and $\mathrm{Si}$ ions can be replaced by $\mathrm{Fe}^{3+}, \mathrm{Cr}^{3+}, \mathrm{Ti}^{4+}$, etc. then we can find a mineral of yellow, brown, or green colour, depending on the deposit [13]. It is constructed of a tetrahedral silicon layer and an octahedral aluminum layer (Fig.1).

Unlike kaolinite, the individual layers are separated here [14]. The outer walls are made of silicon and the inner surface is made of aluminum. Halloysite particle size is in the range of $1-15 \mu \mathrm{m}$ of the length and 10-150 $\mathrm{nm}$ of the diameter, depending on the extraction site [4]. The specific surface area is approximately $26 \mathrm{~m}^{2} / \mathrm{g}$ [15]. The thickness of the hydrated bilayer is $10.2 \AA$ and the anhydrous $7.2 \AA$. The pore volume is $0.08 \mathrm{~cm}^{3}$, of which $99 \%$ are mesopores [16]. Halloysite occurs in two polymorphic forms (Fig. 2, 3). 


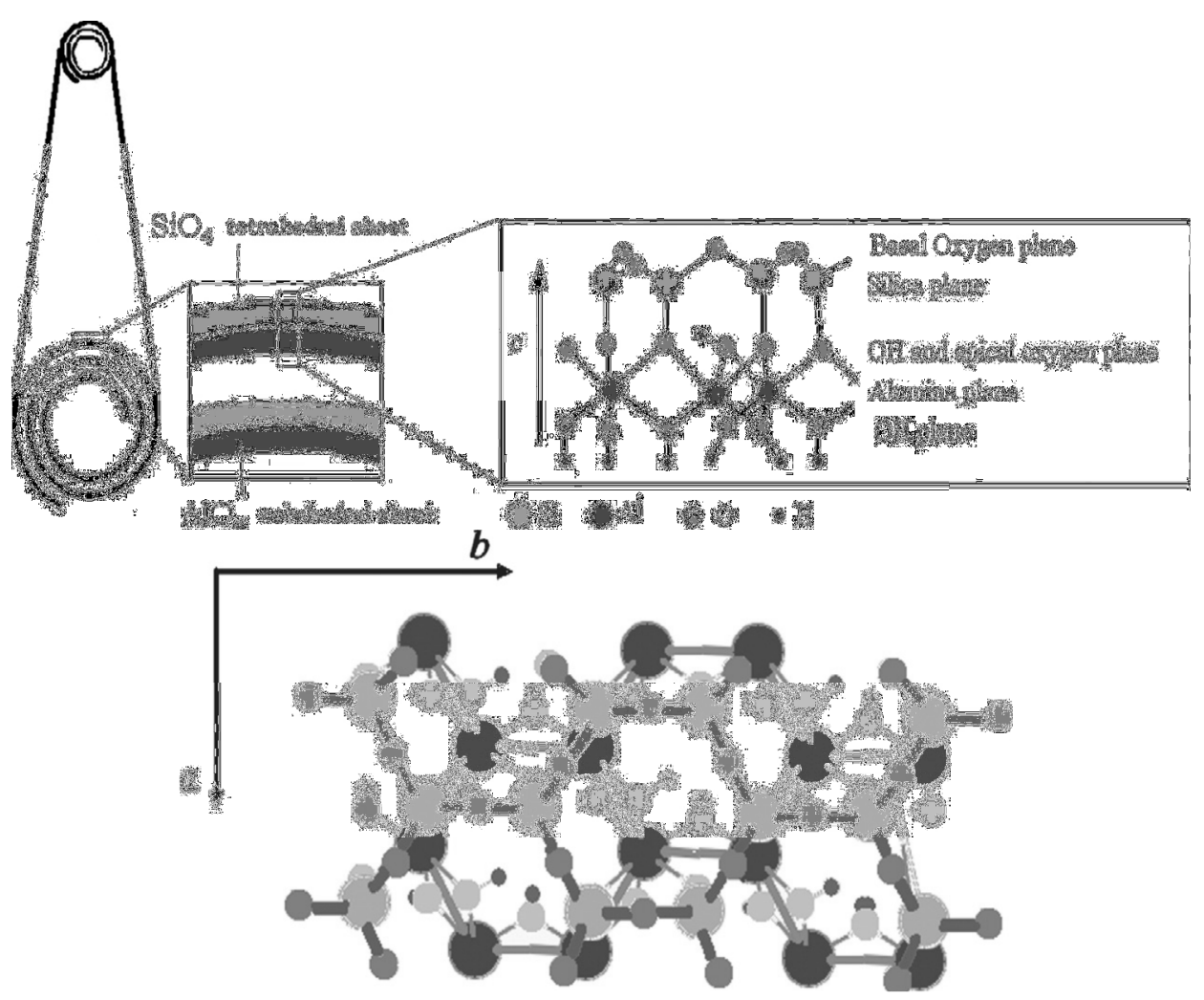

Fig. 1. The structure of halloysite [14].

$10 \AA$-hydrated form, $\mathrm{Al}_{2} \mathrm{Si}_{2} \mathrm{O}_{5}(\mathrm{OH})_{4} \cdot 2 \mathrm{H}_{2} \mathrm{O}$

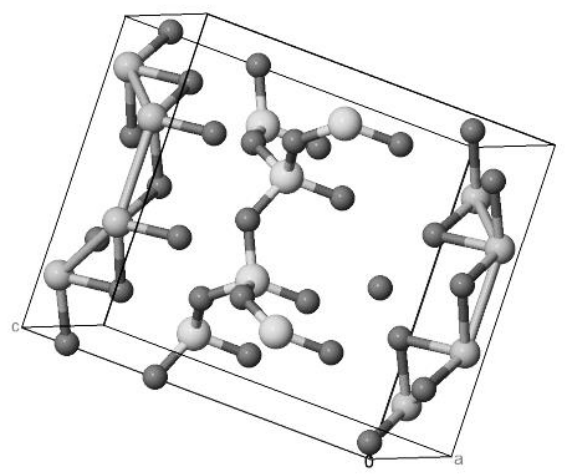

\begin{tabular}{cc}
\hline \multicolumn{2}{c}{ Halloysite 10 } \\
Clml \\
\hline $\mathbf{a}[\tilde{\boldsymbol{A}}]$ & 5.200 \\
$\mathbf{b}[\tilde{\boldsymbol{A}}]$ & 8.920 \\
$\mathbf{c}[\tilde{\boldsymbol{A}}]$ & 10.250 \\
$\boldsymbol{\alpha}\left[\left[^{\circ}\right]\right.$ & 90 \\
$\boldsymbol{\beta}\left[\left[^{\circ}\right]\right.$ & 100 \\
$\gamma\left[^{\circ}\right]$ & 90 \\
\hline
\end{tabular}

Fig. 2. The structure of $10 \AA ̊$ halloysite [17]. 
$7 \AA$-unhydrated form, $\mathrm{Al}_{2} \mathrm{Si}_{2} \mathrm{O}_{5}(\mathrm{OH})_{4}$

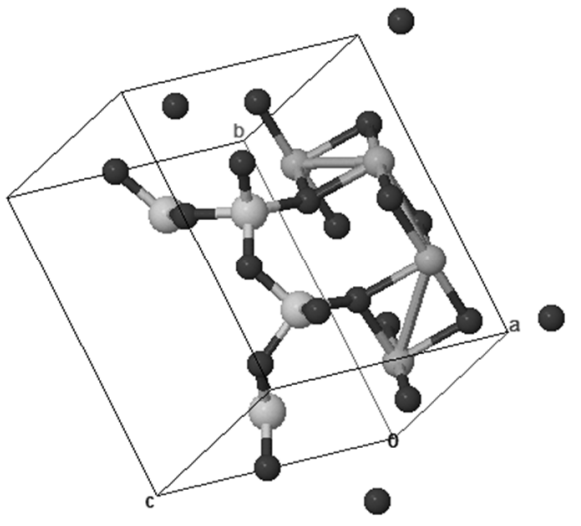

\begin{tabular}{cc}
\hline \multicolumn{2}{c}{ Halloysite $7 \AA$} \\
C1m1 \\
\hline a $[\AA]$ & 5.150 \\
b $[\AA]$ & 8.900 \\
c $[\AA]$ & 7.570 \\
$\boldsymbol{\alpha}\left[{ }^{\circ}\right]$ & 90 \\
$\boldsymbol{\beta}\left[^{\circ}\right]$ & 100 \\
$\gamma\left[^{\circ}\right]$ & 90 \\
\hline
\end{tabular}

Fig. 3. The structure of $7 \AA ̊$ halloysite [17].

The hydrate form is defined as the mineral of a structure of the kaolinite, containing interlayer water molecules that are weakly bonded and can be irreversibly removed. On the diffractogram there is shown an intense peak $10.1 \AA$, which, which heated to a temperature of $110^{\circ} \mathrm{C}$ disappears, a 7.2 $\AA$ gap is formed and anhydrous form is formed [18]. The direction of a coincides with the axis of the nanotube and the direction $c$ is the normal aluminosilic layer. Paramter $\mathrm{c}$ of the elemental cell changes as a result of a dehydration process. This process also causes that the diameter of the nanotube increases by 10-15\%. At a temperature of approx. 500- $600^{\circ} \mathrm{C}$, a mineral undergoes dehydroxylation and there appear a loss of mass, what shows an endothermic peak, then it is stable up to $1000^{\circ} \mathrm{C}$ [19]. Figure 4 shows the XRD for pure halloysite. It indicates that it is a highly crystalline mineral. Intense peak at $4.46 \AA$ indicates the tubular structure of the mineral [18].

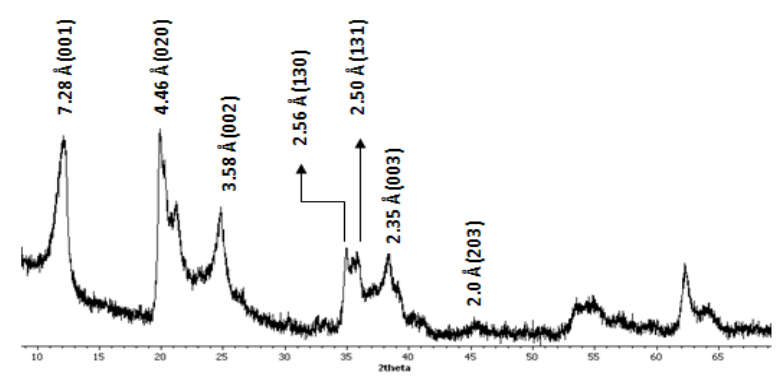

Fig. 4. XRD pattern of halloysite. 
Due to the diversity of geological and crystallization processes, halloysite may be present in various morphological form, tube, spheroidal particles or plates [20, 21, 22]. The most common is the tubular form. It is composed mainly of $\mathrm{SiO}_{2}$ and $\mathrm{Al}_{2} \mathrm{O}_{3}$, in addition, it may contain trace amounts of impurities and contaminations, eg. $\mathrm{TiO}_{2}, \mathrm{CaO}, \mathrm{Na}_{2} \mathrm{O}, \mathrm{K}_{2} \mathrm{O}$. The most common contamination is iron oxide (about 3\% weight). The high iron oxide content may be due to the presence of associated in the mineral iron oxides, as well as isomorphic substitutions higher $\mathrm{Fe}^{3+}$ and $\mathrm{Al}^{3+}+$ in octahedron layers. The iron content influences to the morphology of the mineral [23]. Plate structures contain relatively large amounts of this element and in the pipe it is the least of it. In addition, impurities can generate defects in the structure. Density functional based on tight binding methods confirm the stability of the mineral structure [24]. Halloysite belongs to the group of insulators, it has polydispersive properties [25]. This mineral is less rigid than the carbon nanotubes. Halloysite is environmentally friendly. Is a biocompatible material which is confirmed by cytotoxicity tests. In contrast to the synthetic nanomaterials, halloysite it is cheap and easily available material with many interesting application possibilities [26].

\section{SORPTION PROPERTIES}

Due to its structure, halloysite is characterized by high sorption capacity. Between the individual tiles there are free spaces, so called galleries where can adsorb ions and molecules. In the octahedral and tetrahedral layer there are gaps that because of the diverse potential are also great places of sorption (Fig. 5). The interiors of nanotubes and the surfaces between the grains consist another space.

The unique properties of halloysite are due to differences in the structure of the inner and outside surface of the material. Halloysite nanotube may be a carrier for many substances, for example, drugs [28-34], enzymes [10,11], interiors of the space and between the layers. There can be adsorbed both hydrophilic and hydrophobic particles, depending on the preparation of halloysite. 


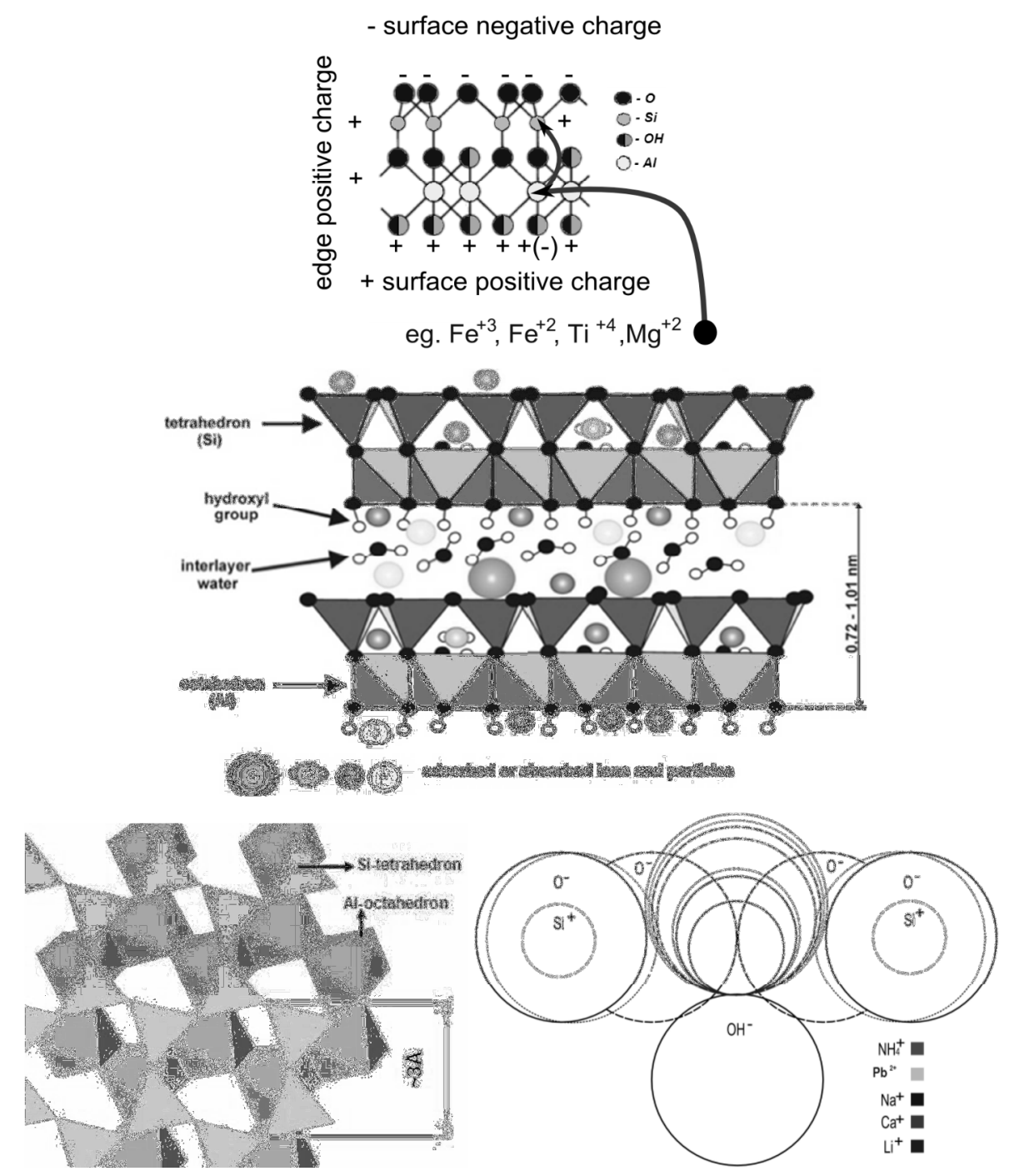

Fig. 5. The sorption area in halloysite.

Aluminum and silicon have different dielectric and ionizing properties, hence the halloysite potential $\xi$ is negative at $\mathrm{pH} \mathrm{6-7} \mathrm{due} \mathrm{to} \mathrm{the} \mathrm{negative}$ potential of $\mathrm{SiO}_{2}$ and a slight impact of the positive charged inner surface of $\mathrm{Al}_{2} \mathrm{O}_{3}$. The occurrence of various charges inside and outside surfaces of the nanotubes allows for selective ability to modify and for the sorption of the compounds of very diverse character. The surface charge of the mineral can be radically altered by cationic substitution. Unlike kaolinite, single plates are not connected here. There is a greater distance between 
the layers than that of kaolinite, which results from the presence of water or different cations. In the kaolinite, the layers are held together by strong hydrogen bonds between the oxygen from the tetraedral layer and the hydrogen from the octahedral hydroxyl group. Halloysite in opposition to kaolinite is characterized by a large number of substitutions of $\mathrm{Al}$ atoms in the octahedral layer with divalent atoms (usually $\mathrm{Mg}$ or $\mathrm{Fe}$ ), trivalent $\mathrm{Fe}$ or tetradent $\mathrm{Ti}$. In addition, $\mathrm{Si}$ in the tetrahedral layer is often replaced by Al. These substitution effects are changing the local microstructure, creating new opportunities for different ties on both sides of a single layer, which is not possible in the case of montmorillonite. Halloysite, in contrast to montmorillonite swells in water to a minimal extent. Single plates are loosely dispersed in the water and act as carriers for other ions. This mineral has a high affinity for monovalent cations: $\mathrm{Ka}, \mathrm{Na} \mathrm{Li}, \mathrm{Cs}$ and it is much higher than for polyvalent cations such as $\mathrm{Ca}$ and $\mathrm{Mg}$ [23]. In halloysite there are two types of hydroxyl groups, internal and external present on the surface of the nanotubes and between the layers. Because of the multi-layer structure, the majority are internal groups. The density of surface hydroxyl groups is lower [35, 36].

Halloysite traps particles in various ways, including adsorption on the internal and external walls, intercalation or loading of the substances within the gap and crystallization. Frost et al. distinguished 3 groups of substances that could intercalate to the halloysite layers. The first group are compounds that form strong hydrogen bonds with silicon tetrahedrons, eg urea, hydrazine, acetamide, etc. These substances must contain $\mathrm{NH}_{2}$ or $\mathrm{OH}$ groups. The second group are substances that can interact with the silica layer by strong dipole interactions, eg dimethylsulfoxide. The third group are organic salts (mainly acetates or propionates) of alkali metals such as potassium or sodium, which can interact with the alumina layer through their anions. The intercalation phenomenon is strongly related to the presence of interlayer water, completely dehydrated halloysite does not show intercalation [37].

\section{APPLICATION}

Halloysite, because of the prevalence of occurrence, ease of functionalization and well-defined structure conducive to sorption processes, enjoys great interest and finds a lot of uses. Historically, halloysite has been used primarily in the ceramic industry because of its high L/D ratio and high temperature resistance [38]. Due to its non- 
toxicity [39], it is used in controlled and prolonged release of drugs [28-35] or bioactive molecules, medical implants [40], tumor cell isolation, nanoreactors [41, 42]. Halloysite-based nanocomposites [43] are also of great interest, particularly in terms of their structural properties, ion exchange or hydrophobicity. Halloysite is a versatile material for loading of various functional groups. It is modified to obtain specific chemical and physical properties. HNTs (Halloysite Nano Tubes) based polymeric nanocomposites [44-53] are characterized by high efficiency, selectivity, mild experimental conditions, simple recovery, reduced thermal expansion, and they are environmentally friendly. Combination with $\mathrm{TiO}_{2}$ [54] increases the removal of organic contaminations, improves photocatalytic activity and dispersibility. Additive in polymer composites allows for enhanced strengths and functionality (eg self-propelling epoxy resin, bone implants). Nanotubes can sorb different substances derived from simple organic and inorganic molecules, to high molecular weight polymers, and biologically active compounds [[55]. They allow sorption in 10-30\% of chemical weights from saturated or molten solutions. There is guaranteed controlled and long-lasting release. Thanks to the nanotube form this mineral has found a wide application in nanotechnology. The presence of opposing charges on the surface of the material allows selective immobilization of charged particles. HNTs can adsorb proteins at $4-8 \%$ by weight in the gaps and on the surface, depending on the protein load. $1 / 3$ of them are released within 10-30h. This adsorption mainly depends on the protein charge and the process conditions. Adsorbed proteins exhibit greater thermal stability and temporary biocatalytic capacities. Due to its high catalytic activity [56-59], it can be used in the conversion process of the oil, in remediation of water $[60,61]$ or in the separation of liquids and gaseous mixtures. In paper production, the modification of wood fibers by halloysite allows for increased brightness and porosity of paper. For the first time, the defect described the complexes of inorganic salts with halloysite, where these salts were incorporated into the mineral structure by replacing the interstitial water molecules. These were, among others chloride, acetate, ammonia or potassium phosphate complexes. The process of intercalation was dependent on the size and charge of the ions [62, 63]. Empty space within the nanotube enables sorption of biomolecules, immobilization of catalysts in the form of metallocomplexes. The mineral can be used for controlled release of pesticides [64], anti-corrosion agents. It allows for prolonged drugs release. It is used to improve the mechanical properties of cement where it increases the compressive strength, as a carrier of 
fertilizers $[65,66]$. Halloysite is also used as a feed additive where it is beneficial for animal health to reduce the emission of gases from farms. The deposition of metal particles such as gold and silver on HNT is of interest because of the ability to induce surface plasmon resonance that can be used in Raman scattering (SERS) and to apply such nanocomposites in photonics $[67,68,69]$. In addition, they can be used in biomedicine for antimicrobial treatment.

Removal of heavy metal ions, certain dyes or some organic contaminants from contaminated water resources is based on the dominant adsorption mechanism. The HNT material-based adsorption process is complex, can include physical and / or chemical sorption, complexation effect, or a combination of adsorption and degradation. Double mechanism is more effective in removing degradable contaminations. HNT can be functionalized as $\mathrm{TiO}_{2}, \mathrm{ZnO}, \mathrm{Ag}, \mathrm{CeO}_{2}$ to remove dyes from aqueous media based on a double mechanism. HNT are able to improve the mechanical strength, thermal stability and separation properties of polymer membranes. Such modified membranes typically are endowed with relatively high hydrophilicity, water jet, mechanical strength and thermal stability. They have important antimicrobial properties desired in the water treatment process.

Halloysite can also be used as a substrate for the production of adsorbents for the adsorption / degradation of phenol-based impurities. Zhang and his co-workers synthesized modified halloysite by chitosan. Halloysite added to the soil improves its physicochemical properties by increasing the $\mathrm{pH}$ and the soil sorption capacity. It increases the amount of biomass compared to control crops in which the soil was contaminated by heavy metals. Hence, halothane can be used as a factor to support the phytoremediation of soils contaminated with heavy metals [70-77]. Zhao and Liu used HNT to remove the cationic methylene dye from aqueous solutions [78-80]. Kilislioglu and Bilgin have studied the adsorption of uranium by HNT.

Halloysite is an alternative to much more expensive carbon nanotubes (Table 1). By using sucrose as a precursor of carbon and halloysite by polymerization and carbonization, porous coals can be obtained. The process is relatively simple and cost is less than by the high temperature carbonation process [81]. 
Table 1. Comparison of halloysite and carbon nanotubes.

\begin{tabular}{lcc}
\cline { 2 - 3 } & Halloysite nanotubes & Carbon annotubes \\
\hline inner diameter/length & $15 \mathrm{~nm} \times 1000 \mathrm{~nm}$ & $2 \mathrm{~nm} \times 1000 \mathrm{~nm}$ \\
biocompability & biocompability & toxic \\
price & $\$ 4$ per kg & $\$ 500$ per kg \\
availability & thousand tons & grams \\
\hline
\end{tabular}

For functionalization of HNT there are various methods, such as the activation of acids, intercalation, thermo-chemical treatment and chemical modification. All these ways affect the improvement of HNT properties. After acid/base treatment, the porosity of the mineral can increase 6-7 times. Sulfuric acid treatment releases several processes such as nanoparticle disaggregation, elimination of mineral contaminations and dissolution of the outer layers. The main purpose of these processes is to break up the structure of the aluminum minerals, which results in an increase in the surface area and BET specific surface area. In the literature we find information that the BET surface and pore volume increase by approximately 13 times. Zhangetal described that the micropores in this case remain intact until the crystalline structure is formed, while the mesopores increase size [82-84].

\section{CONCLUSION}

Halloysite is a widely available, environmentally neutral mineral. It has a large surface area with differentiated sorption mechanisms. Different pore size causes different release times of adsorbed molecules. Due to the low price it is an alternative to carbon nanotubes and is widely used.

\section{REFERENCES}

[1] F. Ferrante, N. Armata, G. Cavallaro, G. Lazzara, J. Phys. Chem., 121 2951 (2017).

[2] G. Kiani, M. Dostali, A. Rostami, A. R. Khataee, Appl. Clay Sci., 54 34-39 (2011).

[3] MDC. Macewan, Nature, 157159 (1946). 
[4] E. Joussein, S. Petit, J. Churchman, B. Theng, D. Right, B. Delvaux, Clay Minerals, 40383 (2005).

[5] S.Y. Lee, S. J. Kim, Applied Clay Science, 2255 (2002).

[6] A. F. Peixoto, A. C. Fernandes, C. Pereira, J. Pires, C. Freire, Microporous and Mesoporous Materials, 219145 (2016).

[7] B. Szczepanik, P. Słomkiewicz, M. Garnuszek, K. Czech, D. Banaś, A. Kubala-Kukuś, I.Stabrawa, I., J. Mol. Struct. 108416 (2015).

[8] P. Yuan, D. Tan, F. Annabi-Bergaya, Applied Clay Science, 75 112-113 (2015).

[9] Y. Zhang, A. Tang, H. Yang, J. Ouyang, Applied Clay Science, 1198 (2016).

[10] J. Tully, R. Yendluri, Y. Lvov, Biomacromolecules, 17615 (2016).

[11] R. Zhai, B. Zhang, L. Liu, Y. Xie, H. Zhang, J. Liu, Catalysis Communications, 12259 (2010).

[12] P. Yuan, P.D. Southon, Z. Liu, M.E.R. Green, J.M. Hook, S.J. Antill, C.J. Kepert, J. Phys. Chem. C 112 (2008) 15742.

[13] J. Marini, E. Pollet, L. Averous, R. E. S. Bretas, Polymer 55, 5226 (2014).

[14] E. Abdullayev, Y. Lvov, Journal of Nanoscience and Nanotechnology, 11 10007 (2011).

[15] T.A. Mammadova, N. V. Hasankhanova, Kh. Sh. Teyubov, E. N. Askerova, T. S. Latifova, V. M. Abbasov, Catal. Sustain. Energy, 228 (2015).

[16] Y. Lvov, W. Wang, L. Zhang, R. Fakhmrllin, Adv. Mater., 281227 (2016).

[17] American Mineralogist Crystal Structure Database.

[18] M. T. Albdiry, H. Ku, B. F. Yousif, Engineering Failure Analysis, 35, 718 (2013).

[19] A. F. Peixoto, A. C. Fernandes, C. Pereira, J. Pires, C. Freire, Microporous and Mesoporous Materials, 219, 145 (2016).

[20] PE Askenasy, JB Dixon, TR McKee, Soil Sci Soc Am J, 3779 (1974).

[21] B. Singh, Clays Clay Miner, 44191 (1996).

[22] L. Yu, H. Wang, Y. Zhang, B. Zhang, J. Liu, Environ. Sci. Nano. 3, 28 (2016).

[23] R. Shemesh, M. Krepker, M. Natan, Y. Danin-Poleg, E. Banin, Y. Kashi, N. Nitzan, A. Vaxman, E. Segal, RSC Adv., 5, 87108 (2015).

[24] L. Guimaraes, A. N. Enyashin, G. Seifert, H. A. Duarte, J. Phys. Chem. C, 114, 11358 (2010).

[25] V. Vergaro, E. Abdullayev, Y. M. Lvov, A. Zeitoun, R. Cingolani, R. Rinaldi, S. Leporatti, Biomacromolecules, 11820 (2010).

[26] S. J. Antill, Aust. J. Chem., 56723 (2003).

[27] M. Du, B. Guo, D. Jia, Polym Int, 59, 574 (2010).

[28] S.R. Levis, P.B. Deasy, Int. J. Pharm., 243, 125-134 (2002).

[29] D. Tan, P. Yuan, F. Annabi-Bergaya, H. Yu, D. Liu, H. Liu, H. He, Microporous Mesoporous Mater., 179, 89-98 (2013). 
[30] D. Tan, P. Yuan, F. Annabi-Bergaya, D. Liu, L.J Wang, H.M. Liu, H.P. He, Appl. Clay Sci., 96 50-55 (2014).

[31] V. Vergaro, Y. M. Lvov, S. Leporatti, Colloids Surf. A Physicochem. Eng. Asp., 396182 (2012).

[32] Y. F. Shi, Z. Tian, Y. Zhang, H. B. Shen, N. Q Jia, Nanoscale Res. Lett., 6 1 (2011).

[33] S. A. Konnova, I. R. Sharipova, T. A. Demina, Y. N. Osin, D. R. Yarullina, O. N. Ilinskaya, Y. M. Lvov, R. F. Fakhrullin, Chem. Commun., 494208 (2013).

[34] K. M. Rao, S. Nagappan, D. J. Seo, C.-S. Ha, Appl. Clay Sci., 33 97-98 (2014).

[35] P. Sakiewicz, R. Nowosielski, W. Pilarczyk, K. Gołombek, M. Lutyński, Journal of Achievements in Materials and Manufacturing Engineering, 48, 117 (2011).

[36] J. Matusik, Chemical Engineering Journal, 246244 (2014).

[37] P. Yuan, P.D. Southon, Z. Liu, M.E.R. Green, J.M. Hook, S.J. Antill, C.J. Kepert, J. Phys. Chem. C, 112 (2008) 15742.

[38] M. Du, B. Guo, D. Jia, Polym Int, 59574 (2010).

[39] E. Abdullayev, Y. Lvov, J. Mater. Chem. B, (2013).

[40] M. Liu, Z. Jia, D. Jia, C. Zhou, Progress in Polymer Science, 391498 (2014).

[41] D. G. Shchukin, G. B. Sukhorukow, R. R. Price, Y. M. Lvov, Small, 1510 (2005).

[42] Y. Zhang, H. M.Yang, Phys.Chem.Miner., 39789 (2012).

[43] J. Marini, E. Pollet, L. Averous, R. E. S. Bretas, Polymer, 555226 (2014).

[44] L.N. Carli, T. S. Daitx, G. V. Soares, J. S. Crespo, R. S. Mauler, Appl. Clay Sci., 87311 (2014).

[45] B. Guo, Y. Lei, F. Chen, X. Liu, M. Du, D. Jia, Appl. Surf. Sci., 2552715 (2008).

[46] N-Y. Ning, Q-J. Yin, F. Luo, Q. Zhang, R. Du, Q. Fu, Polymer, 482374 (2007).

[47] P. Pasbakhsh, H. Ismail, M. N. A. Fauzi, A. A. Bakar, Appl. Clay Sci., 48 405 (2010).

[48] K. Prashantha, M. F. Lacrampe, P. Krawczak, Express Polym. Lett. 5295 (2011).

[49] A. Das, V. Thakur, R. N. Mahaling, A. K. Bhowmick, G. Heinrich, Mater. Des., 312151 (2010).

[50] M. Liu, Z. Jia, D. Jia, C. Zhou, Progress in Polymer Science, 391498 (2014).

[51] L. N. Carli, T. S. Daitx, G. V. Soares, J. S. Crespo, R. S. Mauler, Applied Clay Science, 87311 (2014).

[52] M. T. Albdiry, B. F. Yousif, Materials and Design, 57279 (2014).

[53] E. Bischoff, T. Daitx, D. A. Simon, H. S. Schrekker, S. A. Liberman, R. S. Mauler, Applied Clay Science, 68 112-113 (2015). 
[54] Li, C.P.,Wang, J.Q., Feng, S.Q., Yang, Z.L., Ding, S.J., J. Mater. Chem. A, 18045 (2013).

[55] P.Pasbakhsh, GJ. Churchman, JL. Keeling, Appl Clay Sci, 7447 (2007).

[56] G. S. Machado, K. A. D. d. F. Castro, F. Wypych, S. G. S.Nakagakia, J. Mol. Catal. A Chem., 28399 (2008).

[57] L. Zatta, J. Gardolinski, F. Wypych, Appl.Clay Sci.. 51 165-169 (2011).

[58] S. Barrientos-Ramírez, E. V. Ramos-Fernández, J. Silvestre-Albero, A. Sepúlveda- Escribano, M. M. Pastor-Blas, A. González-Montiel, Micropor. Mesopor. Mat., 120132 (2009).

[59] X. Tang, L. Li, B. Shen, C. Wang, Chemosphere, 911368 (2013).

[60] Y. Zhao, E. Abdullayev, A. Vasiliev, Y. Lvov, J. Colloid Interface Sci., 406121 (2013).

[61] T. P. Ahammed Shabeer, A. Saha, V. T. Gajbhiye, S. Gupta, K. M. Manjaiah, E. Varghese, Water Air Soil Pollut, 22641 (2015).

[62] W. O. Yah, A. Takahara, Y. M. Lvov, J. Am. Chem. Soc., 1341853 (2012).

[63] E. Abdullayev, A. Joshi, W. Wei, Y. Zhao, Y. Lvov, ACS Nano, 67216 (2012).

[64] D. Grabska, M. Raczyńska-Żak, K. Czech, P. M. Słomkiewicz, M. A. Jóźwiak, Applied Clay Science, 114321 (2015).

[65] R. Gao, Q. Meng, J. Li, M. Liu, Y. Zhang, C. Bi, A. Shan, Journal of Animal Science and Biotechnology, 7 (2016).

[66] M. Korczyński, J. Jankowski, D. Witkowska, S. Opaliński, M. Szołtysik, R. Kołacz, Przemyst Chemiczny, 921027 (2013).

[67] P. Liu, M. Zhao, Appl. Surf. Sci., 2553989 (2009).

[68] M. Zieba, J. L. Hueso, M. Arruebo, G. Martínez, J. Santamaría, New J. Chem., 382037 (2014).

[69] K. A. Gonchar, A.V. Kondakova, S. Jana, V.Yu. Timoshenko, A.N. Vasiliev, Optical Properites, 58601 (2016).

[70] L. Yu, H. Wang, Y. Zang, B. Zhang, J. Liu, Environ., 328 (2016).

[71] M. T. Viseras, C. Aguzzi, P. Cerezo, C. Viseras, C. Valenzuela, Micropor. Mesopor. Mat., 108112 (2008).

[72] G. Kiani, Appl. Clay Sci., 90159 (2014).

[73] M. Lutyński, P. Sakiewicz, M. A. Gonzales, Inżynieria Mineralna, 111 (2014).

[74] 74.. C-L. Zhang, S-J. Cui, Y. Wang, Journal of Industrial and Engineering Chemistry, 23, 12 (2015).

[75] T. P. Ahammed Shabeer, A. Saha, V. T. Gajbhiye, S. Gupta, K. M. Manjaiah, E. Varghese, Water Air Soil Pollut, 226, 41 (2015).

[76] F. Ferrante, N. Armata, G. Cavallaro, G. Lazzara, The Journal of Physical Chemistry, 1212951 (2017).

[77] A. Świercz, E. Smorzewska, P. Słomkiewicz, G. Suchanek, Journal of Elementology, 21(2) 559 (2016). 
[78] L. Liu, Y. Z.Wan, Y. D. Xie, R. Zhai, B. Zhang, J. D. Liu, Chem. Eng., 187210 (2012).

[79] G. Kiani, M. Dostali, A. Rostami, A. R. Khataee, Appl. Clay Sci., 5434 (2011).

[80] M. F. Zhao, P. Liu, Micropor. Mesopor. Mat., 112419 (2008).

[81] E. Ruiz-Hitzhy, K. Ariga, Y. Lvov, Bio-inorganic Hybrid Nanomaterials, Wilet-VCH (2008).

[82] R. D. D. V. White, Bavykin, F. C. Walsh, Nanotechnology, 23065705 (2012).

[83] A. B. Zhang, L. Pan, H. Y. Zhang, S. T. Liu, Y. Ye, M. S. Xia, X. G. Chen, Colloids Surf. A Physicochem. Eng. Asp., 396182 (2012).

[84] T. S. Gaaz, A. B. Sulong, A. A. H. Kadhum, M. H. Nassir, A. A. Al-Amiery, Materials, 9, 620 (2016). 